\title{
Nosocomial transmission and outbreaks of coronavirus disease 2019: the need to protect both patients and healthcare workers
}

\author{
Mohamed Abbas ${ }^{1,2^{*}}$ (D), Tomás Robalo Nunes ${ }^{1,3}$, Romain Martischang ${ }^{1}$, Walter Zingg ${ }^{1,3,4}$, Anne Iten ${ }^{1}$, \\ Didier Pittet ${ }^{1,3,4}$ and Stephan Harbarth ${ }^{1,3,4}$
}

\begin{abstract}
Objectives: To compile current published reports on nosocomial outbreaks of severe acute respiratory syndrome coronavirus 2 (SARS-CoV-2), evaluate the role of healthcare workers (HCWs) in transmission, and evaluate outbreak management practices.

Methods: Narrative literature review.

Short conclusion: The coronavirus disease 2019 (COVID-19) pandemic has placed a large burden on hospitals and healthcare providers worldwide, which increases the risk of nosocomial transmission and outbreaks to "non-COVID" patients or residents, who represent the highest-risk population in terms of mortality, as well as HCWs. To date, there are several reports on nosocomial outbreaks of SARS-CoV-2, and although the attack rate is variable, it can be as high as $60 \%$, with high mortality. There is currently little evidence on transmission dynamics, particularly using genomic sequencing, and the role of HCWs in initiating or amplifying nosocomial outbreaks is not elucidated. There has been a paradigm shift in management practices of viral respiratory outbreaks, that includes widespread testing of patients (or residents) and HCWs, including asymptomatic individuals. These expanded testing criteria appear to be crucial in identifying and controlling outbreaks.
\end{abstract}

Keywords: COVID-19, SARS-CoV-2, Infection prevention and control, Healthcare-associated infection, Nosocomial outbreaks

\section{Introduction}

Severe acute respiratory syndrome coronavirus 2 (SARSCoV-2), first described in December 2019, causes coronavirus disease 2019 (COVID-19), and has been declared as a Public Health Emergency of International Concern by World Health Organization (WHO) on 30 January 2020. The number of COVID-19 patients requiring hospitalisation has been high, although data on proportions of cases requiring hospitalisation are not only scarce, but

*Correspondence: mohamed.abbas@hcuge.ch

${ }^{1}$ Infection Control Programme, Geneva University Hospitals and Faculty of Medicine, Geneva, Switzerland

Full list of author information is available at the end of the article also difficult to compare due to different testing strategies and possibly hospital admission criteria. For example, the cumulative numbers of hospitalised cases (and proportions among documented cases) are 4036 (12.7\%) in Switzerland (30 June 2020) [1], 126,695 (42.0\%) in England (16 June 2020) [2], and 103,451 (64.1\%) in France (24 June 2020) [3].

The high numbers of hospitalised patients placed a large burden on healthcare systems, which have had to adapt their surge capacity and infrastructure $[4,5]$. Hospitals admitting COVID-19 patients have practised cohorting in accordance with recommendations from infection prevention and control (IPC) professional societies [6-9]. The resulting hospital-wide colonisation original author(s) and the source, provide a link to the Creative Commons licence, and indicate if changes were made. The images or other third party material in this article are included in the article's Creative Commons licence, unless indicated otherwise in a credit line to the material. If material is not included in the article's Creative Commons licence and your intended use is not permitted by statutory regulation or exceeds the permitted use, you will need to obtain permission directly from the copyright holder. To view a copy of this licence, visit http://creativecommons.org/licenses/by/4.0/. The Creative Commons Public Domain Dedication waiver (http://creativeco mmons.org/publicdomain/zero/1.0/) applies to the data made available in this article, unless otherwise stated in a credit line to the data. 
pressure of SARS-CoV-2 is thus high, potentially exposing healthcare workers (HCWs) and non-COVID-19 patients to nosocomial SARS-CoV-2 acquisition and transmission.

Furthermore, because HCWs are at the interface between healthcare settings and the community, where there is significant transmission, combined with the fact that as essential workers they are not confined, they may also play a role in initiating or amplifying outbreaks in settings such as hospitals $[10,11]$ and long-term care facilities (LTCFs) [12].

The aim of this narrative review is to provide an overview of the existing literature regarding SARS-CoV-2 transmission and outbreaks in healthcare settings, to evaluate the role of HCWs in these outbreaks, and to highlight key IPC practices in outbreak management and prevention.

\section{Methods}

A narrative literature review was performed using the PubMed and Google Scholar databases up to July 22, 2020, searching for current published reports on nosocomial outbreaks of SARS-CoV-2. Publications evaluating the role of healthcare workers (HCWs) in transmission and evaluating outbreak management practices were analysed. In Table 1, a summary of healthcare-associated outbreaks of SARS-CoV-2 involving patients, long-term care facility residents, and HCWs is presented.

\section{Risk of nosocomial transmission to and from healthcare workers}

HCWs are at increased risk of SARS-CoV-2 exposure while caring for COVID-19 patients. However, precise epidemiologic data on SARS-CoV-2 transmission to HCWs are scarce to date, consisting essentially of case series or cross-sectional studies [14, 15], small cohort studies [16], reports from governmental agencies [17], or articles in the lay press [18]. Furthermore, problems with estimates are compounded by uncertain exposure histories and differential screening policies for HCWs [19]. A systematic review identified 15 studies in the scientific literature (including 7 non-peer-reviewed preprints) on burden of SARS-CoV-2 infection in HCWs up to 5 May 2020; however, many of the studies did not provide denominators of exposed HCWs, and the methodological quality was low [13]. Few studies reported on risk factors of SARS-CoV-2 acquisition by HCWs [16, 20].

Currently, attack rates of SARS-CoV-2 in HCWs are difficult to estimate. Data from the Italian Istituto Superiore di Sanità [17] suggested that, as of 6 May 2020, 23,718 HCWs were infected, representing 11.1\% of all microbiologically confirmed cases in the country; however, it is unclear if these were community or healthcare-acquired infections and whether all these HCWs delivered direct care to COVID-19 patients, particularly in hospital settings. An earlier study from a Dutch hospital reported that within 2 weeks of the first Dutch case, $6 \%$ of symptomatic HCWs, representing $0.9 \%$ of the total workforce, were infected [21]. A prospective cohort study in an English hospital showed that the proportion of SARS-CoV-2-infected HCWs was relatively low $(<7 \%)$ and comparable to the prevalence in the community [22]. In another English hospital with a restrictive screening policy (i.e. only in presence of new continuous cough or fever), the proportion of SARS-CoV-2 positive HCWs was 20\% [23]. According to the analysis by Xiang et al. of data from HCWs infected in China, many HCWs who were infected in the healthcare setting were early in the epidemic (i.e. before end of January 2020) and were probably due to either insufficient preparedness in terms of appropriate use of personnel protective equipment (PPE) or due to shortages in PPE [24].

It is also important to analyse COVID-19 related deaths in HCWs. In fact, a government report from England and Wales showed that age-adjusted COVID-19 mortality for HCWs was 10.2 deaths per 100,000 males ( $n=43$ deaths) and 4.8 deaths per 100,000 females $(n=63$ deaths); this was not found to be different from mortality in the general working population [25].

It remains unclear, particularly in settings with extensive community transmission prior to lockdown events, to what extent HCWs were infected in the community or during professional activity (Fig. 1) [16]. For the latter, it is not known whether professional exposure to COVID19 is limited to patient care or to cross-transmission between peers during activities other than patient care. Indeed, as HCWs are younger than the general population [26], and considering that the proportion of asymptomatic or pauci-symptomatic SARS-CoV-2 infections is inversely proportional to increasing age [27], it is plausible that transmission of SARS-CoV-2 to HCWs may occur outside work or during peer-to-peer interaction outside direct patient care. In fact, several studies using whole genome sequencing that suggest that HCWs can be infected in the community and possibly help amplify SARS-CoV-2 outbreaks in the healthcare setting. A study performed in three hospitals in the Netherlands, which combined epidemiological and genetic data, shows that widespread community transmission of SARS-CoV-2 and super-spreading events, such as carnivals, were probable sources of infection in some HCWs [11]. A study performed in 2 skilled nursing facilities in Minnesota, also using epidemiological end genetic information, suggested cross-transmission within the facility. However, some 
Table 1 Summary of healthcare-associated outbreaks of SARS-CoV-2 involving patients, long-term care facility residents, and healthcare workers

\begin{tabular}{|c|c|c|c|c|c|c|}
\hline $\begin{array}{l}\text { Country } \\
\text { Author name }\end{array}$ & $\begin{array}{l}\text { Study design } \\
\text { Setting }\end{array}$ & Source population & $\begin{array}{l}\text { Risk factors } \\
\text { for infection } \\
\text { analysed }\end{array}$ & Attack rate (\%) & $\begin{array}{l}\text { Infection control } \\
\text { measures }\end{array}$ & References \\
\hline \multicolumn{7}{|l|}{ China } \\
\hline Li et al. & $\begin{array}{l}\text { Outbreak investiga- } \\
\text { tion } \\
\text { Hospital }\end{array}$ & $\begin{array}{l}205 \text { patients } \\
148 \text { HCWs }\end{array}$ & Not performed & $\begin{array}{l}6.3 \text { (patients) } \\
8.1 \text { (HCWs) }\end{array}$ & $\begin{array}{l}\text { "Comprehensive } \\
\text { protective measures } \\
\text { such as quarantine } \\
\text { and disinfection" }\end{array}$ & {$[82]$} \\
\hline Wang et al. & $\begin{array}{l}\text { Outbreak investiga- } \\
\text { tion } \\
\text { Hospital }\end{array}$ & $\begin{array}{l}27 \mathrm{HCWs} \\
10 \text { relative }\end{array}$ & Not performed & NR & $\begin{array}{l}\text { Isolation of infected } \\
\text { HCWs }\end{array}$ & {$[32]$} \\
\hline \multicolumn{7}{|c|}{ Hong Kong Special Administrative Region } \\
\hline Cheng et al. & $\begin{array}{l}\text { Suspected hospital } \\
\text { outbreak ("near } \\
\text { miss") }\end{array}$ & 413 HCWs & Not performed & 0.0 & $\begin{array}{l}\text { Reduction of bed } \\
\text { occupancy } \\
\text { Active surveillance } \\
\text { of hospitalised } \\
\text { patients } \\
\text { Linking contact trac- } \\
\text { ing to the hospital } \\
\text { Visitor restriction } \\
\text { Cohorting in AllRs } \\
\text { Segregation of staff } \\
\text { working in high-risk } \\
\text { areas }\end{array}$ & {$[64]$} \\
\hline Wong et al. & $\begin{array}{l}\text { Suspected hospital } \\
\text { outbreak ("near } \\
\text { miss") }\end{array}$ & $\begin{array}{l}71 \text { staff } \\
49 \text { patients }\end{array}$ & N/A & $\begin{array}{l}0.0 \text { (staff) } \\
0.0 \text { (patients) }\end{array}$ & $\begin{array}{l}\text { Quarantine of close } \\
\text { contacts } \\
\text { Symptom screening } \\
\text { and monitoring } \\
\text { Universal masking } \\
\text { Enhanced environ- } \\
\text { mental cleaning }\end{array}$ & {$[20]$} \\
\hline \multicolumn{7}{|l|}{ France } \\
\hline Vanhems et al. & $\begin{array}{l}\text { Outbreak investiga- } \\
\text { tion } \\
\text { Hospital }\end{array}$ & $\begin{array}{l}35 \text { patients } \\
\text { NR staff }\end{array}$ & Not performed & $\begin{array}{l}20.0 \text { (patients) } \\
\text { NR (staff) }\end{array}$ & $\begin{array}{l}\text { "Strict infection con- } \\
\text { trol measures" } \\
\text { "Close monitoring of } \\
\text { suspected cases" }\end{array}$ & {$[83]$} \\
\hline $\begin{array}{l}\text { Luong-Nguyen } \\
\text { et al. }\end{array}$ & $\begin{array}{l}\text { Outbreak investiga- } \\
\text { tion } \\
\text { Hospital }\end{array}$ & 301 patients & Not performed & 4.9 (patients) & $\begin{array}{l}\text { Reduction of bed } \\
\text { occupancy } \\
\text { Screening patients on } \\
\text { admission } \\
\text { Visitor restrictions } \\
\text { Universal masking } \\
\text { Cohorting }\end{array}$ & {$[61]$} \\
\hline \multicolumn{7}{|l|}{ Germany } \\
\hline Kabesch et al. & $\begin{array}{l}\text { Outbreak investiga- } \\
\text { tion } \\
\text { Hospital }\end{array}$ & 562 staff & Not performed & 5.2 & $\begin{array}{l}\text { Symptom monitoring } \\
\text { of close contacts } \\
\text { Universal masking } \\
\text { Physical distancing in } \\
\text { non-clinical areas }\end{array}$ & {$[62]$} \\
\hline Schneider et al. & $\begin{array}{l}\text { Hospital-based sur- } \\
\text { veillance }\end{array}$ & $66 \mathrm{HCWs}$ & N/A & 0.0 & $\begin{array}{l}\text { Ban on elective } \\
\text { surgery (incl. outpa- } \\
\text { tient clinics) } \\
\text { Visitor restrictions } \\
\text { Universal masking } \\
\text { Screening prior to } \\
\text { transfer in rehabilita- } \\
\text { tion }\end{array}$ & [63] \\
\hline
\end{tabular}


Table 1 (continued)

\begin{tabular}{|c|c|c|c|c|c|c|}
\hline $\begin{array}{l}\text { Country } \\
\text { Author name }\end{array}$ & $\begin{array}{l}\text { Study design } \\
\text { Setting }\end{array}$ & Source population & $\begin{array}{l}\text { Risk factors } \\
\text { for infection } \\
\text { analysed }\end{array}$ & Attack rate (\%) & $\begin{array}{l}\text { Infection control } \\
\text { measures }\end{array}$ & References \\
\hline $\begin{array}{l}\text { Schwierzeck } \\
\text { et al. }\end{array}$ & $\begin{array}{l}\text { Outbreak investiga- } \\
\text { tion } \\
\text { Dialysis unit }\end{array}$ & $\begin{array}{l}28 \text { HCWs (8 lab con- } \\
\text { firmed) } \\
13 \text { patients ( } 3 \text { lab } \\
\text { confirmed) } \\
7 \text { relatives (1 lab } \\
\text { confirmed) }\end{array}$ & Exposure analysis only & NR & $\begin{array}{l}\text { Quarantine of } \\
\text { exposed HCWs (or } \\
\text { work with surgical } \\
\text { mask if asympto- } \\
\text { matic) } \\
\text { Symptom monitoring } \\
\text { Expanded testing } \\
\text { criteria }\end{array}$ & [47] \\
\hline \multicolumn{7}{|l|}{ Singapore } \\
\hline Wee et al. & $\begin{array}{l}\text { Outbreak investiga- } \\
\text { tion } \\
\text { Hospital }\end{array}$ & 14 HCWs & Not performed & NR & $\begin{array}{l}\text { Self-isolation of HCWs } \\
\text { if symptomatic or in } \\
\text { close contact } \\
\text { Symptom monitoring } \\
\text { Syndromic surveil- } \\
\text { lance of HCWs (staff } \\
\text { clinic) }\end{array}$ & {$[84]$} \\
\hline Ng et al. & $\begin{array}{l}\text { Suspected hospital } \\
\text { outbreak ("near } \\
\text { miss") }\end{array}$ & $41 \mathrm{HCWs}$ & Not performed & 0.0 & $\begin{array}{l}\text { Self-isolation of HCWs } \\
\text { in close contact } \\
\text { Symptom monitoring } \\
\text { Expanded testing } \\
\text { criteria }\end{array}$ & {$[48]$} \\
\hline \multicolumn{7}{|l|}{ South Africa } \\
\hline Lessels et al. & $\begin{array}{l}\text { Outbreak investiga- } \\
\text { tion } \\
\text { Hospital }\end{array}$ & $\begin{array}{l}80 \text { staff } \\
39 \text { inpatients }\end{array}$ & Not performed & $\begin{array}{l}4.0 \text { (staff) } \\
\text { NR (patients) }\end{array}$ & $\begin{array}{l}\text { Surveillance or } \\
\text { self-monitoring of } \\
\text { exposed contacts } \\
\text { (HCWs \& patients) } \\
\text { Quarantine of } \\
\text { selected HCWs } \\
\text { Cohorting } \\
\text { Cancellation of } \\
\text { elective surgical } \\
\text { procedures } \\
\text { Expanded testing } \\
\text { criteria (all staff) } \\
\text { Enhanced environ- } \\
\text { mental cleaning } \\
\text { Hospital closure }\end{array}$ & [49] \\
\hline \multicolumn{7}{|l|}{ United Kingdom } \\
\hline Graham et al. & $\begin{array}{l}\text { Outbreak investiga- } \\
\text { tion } \\
\text { Nursing homes }(n=4)\end{array}$ & $\begin{array}{l}70 \text { staff } \\
394 \text { residents }\end{array}$ & Not performed & $\begin{array}{l}4.3 \text { (staff) } \\
32.0 \text { (residents) }\end{array}$ & $\begin{array}{l}\text { Self-isolation of HCWs } \\
\text { if symptomatic or in } \\
\text { close contact } \\
\text { Expanded testing cri- } \\
\text { teria (serial testing) } \\
\text { Cohort wards }\end{array}$ & {$[39]$} \\
\hline Rickman et al. & $\begin{array}{l}\text { Outbreak investiga- } \\
\text { tion } \\
\text { Hospital }\end{array}$ & 435 patients & Not performed & $\begin{array}{l}\text { NR } \\
\text { (15.0\% of all COVID-19 } \\
\text { cases) }\end{array}$ & $\begin{array}{l}\text { Cohort wards } \\
\text { Visitor restrictions } \\
\text { Expanded testing } \\
\text { criteria } \\
\text { Cohorting suspected } \\
\text { cases } \\
\text { Staff screening } \\
\text { Universal masking }\end{array}$ & {$[50]$} \\
\hline
\end{tabular}

healthcare workers also presented genetically distinct strains, probably acquired in the community setting [12].

A large hospital-wide screening programme has shown that 30 of 61 (49\%) SARS-CoV-2 positive HCWs were asymptomatic, though $40 \%$ of them were found to have had mild symptoms preceding a positive test (i.e. were pauci-symptomatic) [28]. A pre-pandemic survey suggested that $56 \%$ of $\mathrm{HCWs}$ with any influenza-like 
Table 1 (continued)

\begin{tabular}{|c|c|c|c|c|c|c|}
\hline $\begin{array}{l}\text { Country } \\
\text { Author name }\end{array}$ & $\begin{array}{l}\text { Study design } \\
\text { Setting }\end{array}$ & Source population & $\begin{array}{l}\text { Risk factors } \\
\text { for infection } \\
\text { analysed }\end{array}$ & Attack rate (\%) & $\begin{array}{l}\text { Infection control } \\
\text { measures }\end{array}$ & References \\
\hline \multicolumn{7}{|l|}{ United States } \\
\hline Arons et al. & $\begin{array}{l}\text { Outbreak investiga- } \\
\text { tion } \\
\text { Nursing home }\end{array}$ & $\begin{array}{l}89 \text { residents } \\
\text { Staff data NR }\end{array}$ & Not performed & $\begin{array}{l}64.0 \text { (residents) } \\
\text { NR (staff) }\end{array}$ & $\begin{array}{l}\text { Visitor restrictions } \\
\text { Cancellation of com- } \\
\text { munal activities } \\
\text { Facility-wide transmis- } \\
\text { sion precautions } \\
\text { (PPE use) } \\
\text { Expanded testing } \\
\text { criteria (serial preva- } \\
\text { lence) } \\
\text { Cohorting? }\end{array}$ & {$[34]$} \\
\hline Baker et al. & $\begin{array}{l}\text { Outbreak investiga- } \\
\text { tion } \\
\text { Hospital }\end{array}$ & $\begin{array}{l}1 \text { index patient } \\
44 \mathrm{HCWs}\end{array}$ & Not performed & 4.7 (staff) & $\begin{array}{l}\text { Universal masking } \\
\text { Symptom monitoring } \\
\text { Expanded testing cri- } \\
\text { teria (for contacts) }\end{array}$ & {$[51]$} \\
\hline Dora et al. & $\begin{array}{l}\text { Outbreak investiga- } \\
\text { tion } \\
\text { Nursing home }\end{array}$ & $\begin{array}{l}99 \text { residents } \\
136 \text { staff }\end{array}$ & $N R$ & $\begin{array}{l}19.2 \text { (residents) } \\
4.4 \text { (staff) }\end{array}$ & $\begin{array}{l}\text { Expanded testing } \\
\text { criteria (serial preva- } \\
\text { lence) } \\
\text { Symptom screening } \\
\text { Cohorting } \\
\text { Restricting staff move- } \\
\text { ment across wards }\end{array}$ & [52] \\
\hline $\begin{array}{l}\text { Heinzerling } \\
\text { et al. }\end{array}$ & $\begin{array}{l}\text { Outbreak investiga- } \\
\text { tion } \\
\text { Hospital }\end{array}$ & $121 \mathrm{HCWs}$ & $\begin{array}{l}\text { Case-control study } \\
\text { (COVID-19 vs. non- } \\
\text { COVID-19 HCWs) }\end{array}$ & 2.5 & $\begin{array}{l}\text { Self-isolation in case } \\
\text { of close contact } \\
\text { Symptom monitoring }\end{array}$ & {$[85]$} \\
\hline $\begin{array}{l}\text { McMichael } \\
\text { et al. }\end{array}$ & $\begin{array}{l}\text { Outbreak investiga- } \\
\text { tion } \\
\text { Nursing home } \\
\text { network }\end{array}$ & $\begin{array}{l}101 \text { residents } \\
50 \text { HCWs } \\
16 \text { visitors }\end{array}$ & Not performed & NR & $\begin{array}{l}\text { PPE training } \\
\text { Hand hygiene assess- } \\
\text { ments } \\
\text { Audits of PPE use } \\
\text { Reviews of environ- } \\
\text { mental cleaning } \\
\text { and disinfection } \\
\text { practices } \\
\text { Mandatory screening } \\
\text { of HCWs } \\
\text { Visitor restrictions } \\
\text { Physical distancing } \\
\text { Restricting resident } \\
\text { movement and } \\
\text { group activities }\end{array}$ & {$[40]$} \\
\hline Kimball et al. & $\begin{array}{l}\text { Outbreak investiga- } \\
\text { tion } \\
\text { Nursing homes }\end{array}$ & 82 residents & Not performed & 28.0 & $\begin{array}{l}\text { Expanded testing } \\
\text { criteria } \\
\text { Universal isolation } \\
\text { precautions } \\
\text { Visitor restrictions } \\
\text { Symptom monitoring } \\
\text { (residents) } \\
\text { Fever screening } \\
\text { (HCWs) }\end{array}$ & {$[41]$} \\
\hline Patel et al. & $\begin{array}{l}\text { Outbreak investiga- } \\
\text { tion } \\
\text { Nursing home }\end{array}$ & $\begin{array}{l}127 \text { residents } \\
112 \text { staff }\end{array}$ & & $\begin{array}{l}26.0 \text { (residents) } \\
17.0 \text { (staff) }\end{array}$ & $\begin{array}{l}\text { Expanded testing } \\
\text { criteria } \\
\text { Symptom screening } \\
\text { (visitors, staff) } \\
\text { Visitor restriction } \\
\text { Universal masking } \\
\text { Cohorting } \\
\text { Enhanced training } \\
\text { (hand hygiene, envi- } \\
\text { ronmental cleaning, } \\
\text { etc.) }\end{array}$ & [53] \\
\hline
\end{tabular}


Table 1 (continued)

\begin{tabular}{|c|c|c|c|c|c|c|}
\hline $\begin{array}{l}\text { Country } \\
\text { Author name }\end{array}$ & $\begin{array}{l}\text { Study design } \\
\text { Setting }\end{array}$ & Source population & $\begin{array}{l}\text { Risk factors } \\
\text { for infection } \\
\text { analysed }\end{array}$ & Attack rate (\%) & $\begin{array}{l}\text { Infection control } \\
\text { measures }\end{array}$ & References \\
\hline Roxby et al. & $\begin{array}{l}\text { Outbreak investiga- } \\
\text { tion } \\
\text { Nursing homes }\end{array}$ & $\begin{array}{l}80 \text { residents } \\
62 \text { staff members }\end{array}$ & Not performed & $\begin{array}{l}3.8 \text { (residents) } \\
3.2 \text { (staff) }\end{array}$ & $\begin{array}{l}\text { Physical distancing } \\
\text { Visitor restrictions } \\
\text { Restriction of com- } \\
\text { munal activities } \\
\text { Self-isolation of symp- } \\
\text { tomatic HCWs } \\
\text { Enhanced environ- } \\
\text { mental cleaning } \\
\text { Expanded testing cri- } \\
\text { teria (serial testing) }\end{array}$ & [54] \\
\hline
\end{tabular}

AllR airborne infection isolation room, CDC Centers for Disease Control and Prevention (US), COVID-19 coronavirus disease 2019, HA/ healthcare-associated infection, HCW healthcare worker, NHC National Health Commission (People's Republic of China), NR not reported or performed, PPE personal protective equipment

symptoms would go to work; the proportion of those with "mild" symptoms (e.g. sore throat, nasal discharge, etc.) who would still go to work is higher (89-99\%) [29]. This also seems true for COVID-19; a report of HCWs screened during an outbreak in a LTCF in the US showed that $64.6 \%$ of HCWs with confirmed SARS-CoV-2 infection worked while they were symptomatic, and for a median duration of 2 days (range 1-10) [30]. This clearly indicates a high risk of HCWs being vectors of healthcare-associated viral respiratory illness, such as COVID19, when caring for uninfected patients [31].

A report of a nosocomial outbreak involving $25 \mathrm{HCWs}$ with microbiologically-documented SARS-CoV-2 infection spanning from January to February 2020 in Wuhan, China, was published in June [32]. The outbreak started in the Department of Neurosurgery of a hospital in Wuhan where HCWs $(n=12)$ were managing 2 index patients with documented SARS-CoV-2 infection (unclear if healthcare-associated). HCWs of other departments $(n=13)$ were subsequently infected, as were 10 of 43 family members of all HCWs. A detailed contact tracing investigation identified 9 transmission clusters, with 2 index patients infecting $5 \mathrm{HCWs}$ with reasonable probability, and 2 suspected transmission events. These HCWs were involved in probable transmission to 1 other HCW and suspected transmission to 6 additional HCWs. Genome sequencing was performed on samples obtained from $11 \mathrm{HCWs}$ and 1 family member; the phylogenetic tree showed 4 clades, with one clade involving $5 \mathrm{HCWs}$ and a family member. This detailed report clearly suggests that HCWs can transmit SARS-CoV-2 to other HCWs. Unfortunately, the sequences of the index patients were not available, and therefore the first step in the presumed transmission chain could not be analysed genetically.

In summary, since HCWs are at the interface between hospitals and LTCFs on the one hand and the community on the other, they may serve as reservoirs, vectors, or victims of SARS-CoV-2 cross-transmission.

\section{Definitions of healthcare-associated COVID-19 in hospitalized patients}

Currently, there are no universally accepted definitions of healthcare-associated COVID-19. Table 2 summarises a number of official published definitions of healthcareassociated COVID-19. Considering the uncertainty revolving around atypical symptoms (or lack thereof), incubation periods, transmission in the pre-symptomatic stages of infection, and the controversy over asymptomatic infection, this is hardly surprising. This is also compounded by the fact that admission-based screening practices vary by epidemiology (mid-wave vs. postwave), place (LTCF vs. acute hospital ward), availability of testing, and country. Nonetheless, a balance should be sought between a sensitive or specific case definition that is applicable for outbreak management. Conservative definitions (e.g. the 48-h post-admission rule, usually applied for healthcare-associated infections) are likely to be more sensitive in detecting healthcareassociated COVID-19 for operational purposes, such as triggering outbreak responses. Yet, they will potentially overestimate the true number of healthcare-associated COVID-19, as the median incubation period until the development of COVID-19 symptoms is approximately 5 days [33]. Therefore, by using the 48 -h post-admission rule, patients with probable community acquired infections will still be included in this definition.

\section{Healthcare-associated transmission of SARS-CoV-2 in hospitalized patients or residents}

The fact that HCWs can acquire SARS-CoV-2 in the community, combined with the practice that many hospitals admit both COVID-19 and non-COVID-19 patients at the same sites, produces a high colonisation 


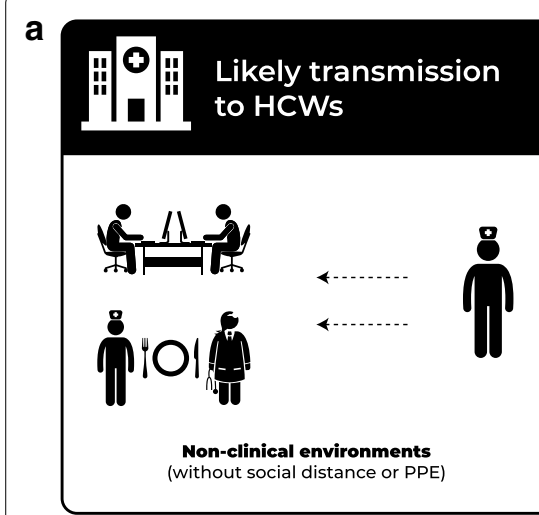

a
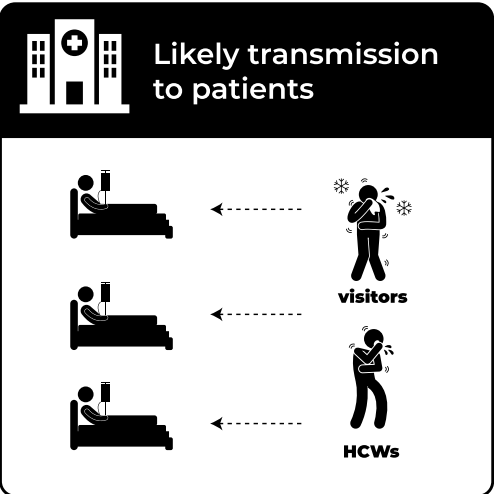

a
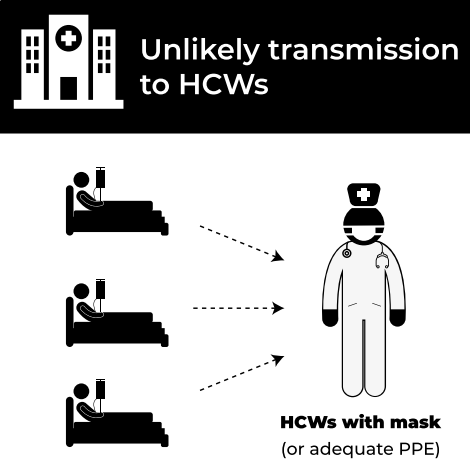

Fig. 1 Transmission pathways of SARS-CoV-2. a Likely modes of SARS-CoV-2 transmission to HCWs in healthcare environments (both direct patient care and non-clinical settings) and in the community. b Likely modes of SARS-CoV-2 transmission to patients in healthcare settings. $\mathbf{c}$ Unlikely modes of SARS-CoV-2 transmission to HCWs in healthcare environments
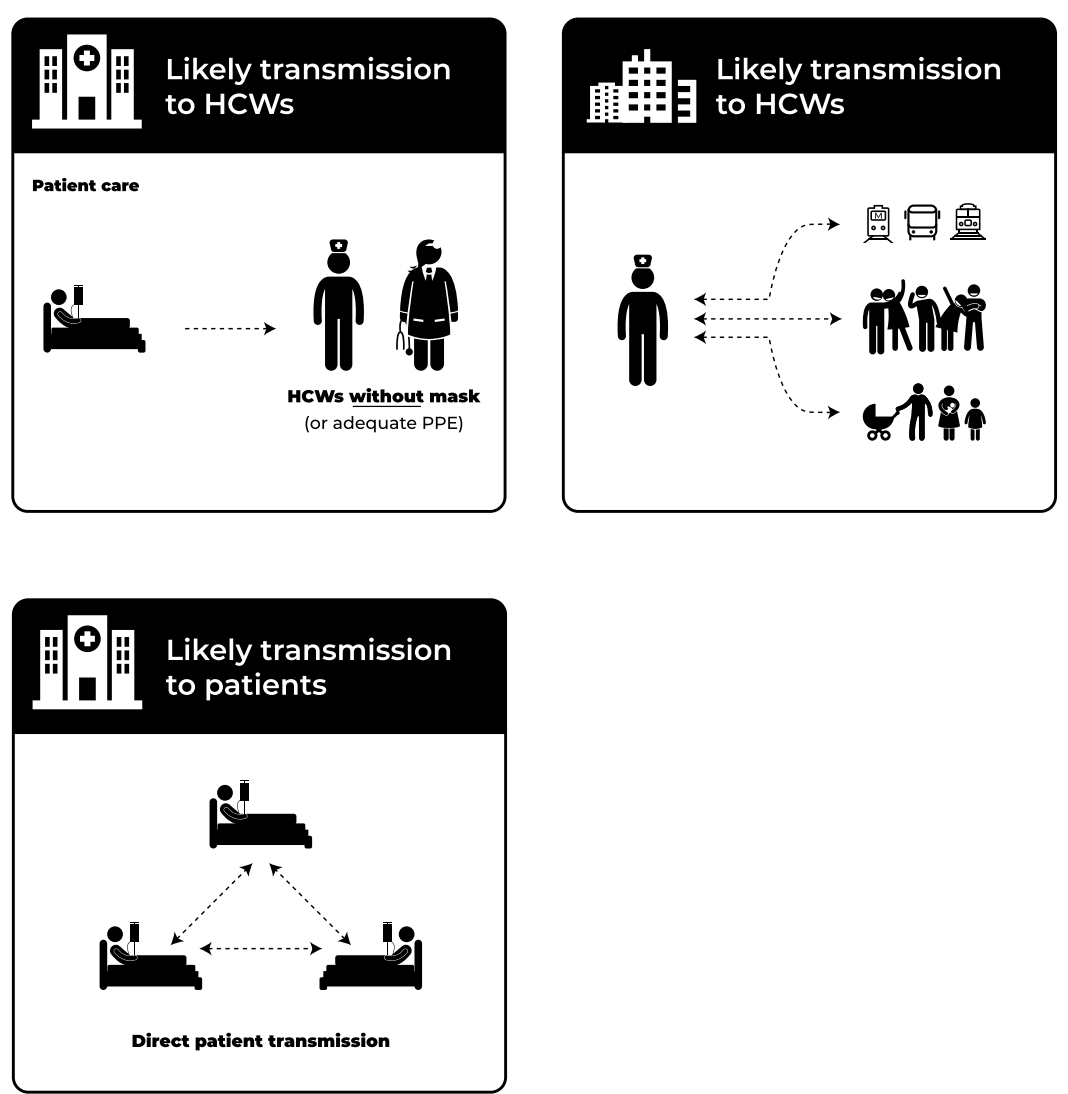

\section{Likely transmission}

pressure of SARS-CoV-2 in hospital settings, exposing both susceptible patients and HCWs to the risk of healthcare-associated SARS-CoV-2 infection. Although current recommendations highlight the importance of cohorting COVID-19 patients, truly isolating them from susceptible non-COVID-19 patients is not always possible. In fact, the long incubation period of SARS-CoV-2 infection and the high proportion of asymptomatic/ pauci symptomatic infections, even in LTCFs [34], creates the perfect environment for silent transmission in the healthcare setting. In particular, elderly patients who are hospitalised in geriatric wards, or transferred to rehabilitation clinics, as well as those in LTCFs, are frail and have comorbidities making them more vulnerable to complications resulting from SARS-CoV-2 infections [35]. Moreover, the longer duration of hospital stay 
Table 2 Official definitions of healthcare-associated coronavirus disease 2019 (COVID-19) cases and outbreaks

\begin{tabular}{|c|c|c|c|}
\hline Country & Definition of cases & Definition of outbreak & References \\
\hline England & $\begin{array}{l}\text { Probable healthcare-associated COVID-19: a single inpatient } \\
\text { who develops COVID-19 more than } 7 \text { days after hospital } \\
\text { admission }\end{array}$ & $\begin{array}{l}\text { Two or more cases in a single setting are detected that have } \\
\text { become symptomatic or detected on screening on or } \\
\text { after day eight of hospital admission }\end{array}$ & {$[86]$} \\
\hline Canada & Not reported & $\begin{array}{l}\text { LTCFs: a single laboratory-confirmed case of COVID-19 in a } \\
\text { staff member (or resident) }\end{array}$ & {$[87]$} \\
\hline Ireland & $\begin{array}{l}\text { - Onset of compatible symptoms } \geq 7 \text { days after admission } \\
\text { - Onset of compatible symptoms 3-6 after admission if } \\
\text { epidemiologically linked to hospital exposure } \\
\text { - Onset of clinical features of COVID-19 on day } 1 \text { or } 2 \text { after } \\
\text { admission are considered community acquired unless } \\
\text { epidemiologically linked to hospital exposure during a } \\
\text { recent hospital admission } \\
\text { - If onset of clinical features cannot be defined, a case by } \\
\text { case assessment is required taking account of the date of } \\
\text { sampling relative to the date of admission, the CT value } \\
\text { of the test result and epidemiological evidence of a link to } \\
\text { hospital exposure. }\end{array}$ & Not reported & {$[88]$} \\
\hline Switzerland & $\begin{array}{l}\text { - Patient with new onset of COVID-19 compatible signs and } \\
\text { symptoms* at least } 5 \text { days after hospital admission and a } \\
\text { positive PCR result and/or thorax CT scan suggestive of } \\
\text { COVID-19 } \\
\text { - For hospitals with universal admission screening: Patient } \\
\text { with negative PCR on admission and new onset of COVID- } \\
19 \text { compatible symptoms and/or a positive PCR result at } \\
\text { least } 5 \text { days after hospital admission }\end{array}$ & $\begin{array}{l}\text { Detection of } \geq 3 \text { nosocomial COVID-19 cases with a pos- } \\
\text { sible epidemiological (temporal and local) link }\end{array}$ & {$[89]$} \\
\hline United States & $\begin{array}{l}\text { - NOT considered nursing home onset COVID-19: } \\
\text { - Residents who were known to have COVID-19 on admis- } \\
\text { sion to the facility and were placed into appropriate } \\
\text { Transmission-Based Precautions to prevent transmission } \\
\text { to others in the facility. } \\
\text { - Residents who were placed into Transmission-Based } \\
\text { Precautions on admission and developed SARS-CoV-2 } \\
\text { infection within } 14 \text { days after admission }\end{array}$ & $\begin{array}{l}\text { Notification required in case of: } \\
\text { Residents or HCP with suspected or confirmed COVID-19 } \\
\text { Residents with severe respiratory infection resulting in } \\
\text { hospitalization or death } \\
\geq 3 \text { residents or HCP with new-onset respiratory symptoms } \\
\text { within } 72 \text { h of each other }\end{array}$ & {$[90,91]$} \\
\hline $\begin{array}{l}\text { European } \\
\text { Centre for } \\
\text { Disease } \\
\text { Preven- } \\
\text { tion and } \\
\text { Control }\end{array}$ & $\begin{array}{l}\text { - Community-associated COVID-19 (CA-COVID-19): Symp- } \\
\text { toms present on admission or with onset on day } 1 \text { or } 2 \\
\text { after admission } \\
\text { - Symptom onset on days 3-7 and a strong suspicion of } \\
\text { community transmission.. } \\
\text { - Indeterminate association (IA-COVID-19): Symptom onset } \\
\text { on day 3-7 after admission, with insufficient information } \\
\text { on the source of infection to assign to another category. } \\
\text { - Probable healthcare-associated COVID-19 (HA-COVID-19): } \\
\text { Symptoms onset on day 8-14 after admission } \\
\text { - Symptom onset on day 3-7 and a strong suspicion of } \\
\text { healthcare transmission. } \\
\text { - Definite HA-COVID-19: Symptom onset on day } \geq 14 \text { after } \\
\text { admission }\end{array}$ & Not provided & $\begin{array}{l}\text { https:// } \\
\text { www. } \\
\text { ecdc. } \\
\text { europ } \\
\text { a.eu/en/ } \\
\text { covid } \\
\text {-19/surve } \\
\text { illance/ } \\
\text { surveillan } \\
\text { ce-defin } \\
\text { itions. } \\
\text { Accessed } \\
\text { Decem- } \\
\text { ber } 26, \\
2020\end{array}$ \\
\hline
\end{tabular}

increases the risk of healthcare-acquired COVID-19. Indeed, during the pandemic, many hospitals restricted or suppressed visits, meaning that healthcare-associated SARS-CoV-2 infections were almost exclusively due to patient-to-patient or HCW-to-patient transmission.

Outbreaks in LTCFs are a major public health concern, yet few countries report data. In England, data from the government show that up to 21 June 2020, there were 6,538 SARS-CoV-2 outbreaks in a total of 15,507 facilities [36]. In France, there were 3,375 clusters ( $\geq 1$ case) in nursing homes, out of a total of 8,158 reports that involved 34,283 COVID-19 cases [3]. In the canton of Geneva, the region of Switzerland with the highest burden of COVID-19, $40.3 \%$ of all deaths were in nursing homes [37]. In Belgium, 8.7\% of all confirmed COVID-19 cases were in nursing home residents [38]. To date, there are few published reports of healthcare-associated outbreaks (Table 1), suggesting that this is a sensitive issue and that there may be some degree of publication bias. 
An outbreak of SARS-CoV-2 across 4 nursing homes in London was reported involving 394 residents and 70 staff [39]. Extensive testing, including on asymptomatic residents, showed a high attack rate in residents (32.0\%), with high mortality (26.0\%). Attack rates in asymptomatic staff $(n=70)$ were $4.0 \%$, although the authors report that absence due to sickness or selfisolation were three times higher than expected. Genotyping of 19 strains showed multiple distinct clusters within 1 nursing home, and high similarity of sequences within 4 clusters [39].

An outbreak of SARS-Cov-2 across nine LTCFs in Washington, US, involving 101 residents and 50 staff members was recently described [40]. Although the attack rates of the facilities were not reported, the proportion of COVID-19 residents that required hospitalisation was high (54.5\%). A separate study from one of the nine LTCFs reported an attack rate of 30\% (23/76); testing was initiated after one HCW had a positive SARSCoV-2 PCR [41]. A third report from the same outbreak estimated a doubling time that was faster in the facility (3.4 days) than what was observed in the community (5.5 days), demonstrating the potential of uncontrolled transmission in these settings [34]. In that facility, 57 of 89 residents $(64 \%)$ had documented SARS-CoV-2 infection, as did 26/138 (19\%) of staff members [34]. Sequencing of a convenience sample of 39 genomes from 34 residents identified 2 clusters [34].

Phylogenetic trees were produced in two of these reports, but only from patient samples and not from HCWs [34, 39]. None of these studies evaluated the transmission dynamics, in particular the direction of chains of transmission.

There are few data on risk of healthcare-associated COVID-19 in the hospital setting. One early study from China, with a sample size of 138 patients suggested that $41 \%$ of the cases were believed to be healthcare-associated [42]. Reports in the lay press suggest that in England $5-7 \%$ of all COVID-19 cases are healthcare-associated [43]. A retrospective study performed in a teaching hospital in London revealed that 15\% of COVID-19 in patients between 2 March and 12 April were definitely or probably nosocomial, with a case a fatality of $36 \%$. After the introduction of better infection control practices, the nosocomial infection rates improved.

A prospective epidemiological surveillance in a hospital trust in Cambridge combined epidemiological and genetic data to investigate causes of healthcare-associated COVID-19 [44]. The investigation revealed the existence of 35 distinct clusters, with $22 \%$ having no epidemiological evidence of transmission, and healthcareassociated clusters in 9 "non-COVID" wards involving both patients and HCWs. The results of the ongoing investigation help to adapt IPC practices, and to rule out transmission events that were initially epidemiologically suspected.

\section{Outbreak control strategies}

Considering the high transmissibility of SARS-CoV-2 in the community $\left(\mathrm{R}_{0} 3.8\right.$ [2.4-5.6]) [45] and the associated high morbidity and mortality in elderly and/or comorbid patients, the preferred outbreak control strategy is to prevent its occurrence [46].

Several control measures have been implemented in the reported healthcare-associated outbreaks, although the specific effects of these measures are difficult to ascertain because they are often simultaneously implemented. Common elements include expanded testing criteria [34, $39,41,47-54]$, including testing asymptomatic patients/ residents and healthcare workers, as well as serial testing or repeat point-prevalence surveys. This represents a true paradigm shift in management of nosocomial outbreaks; indeed, apart from cases where asymptomatic carriers of multidrug-resistant bacteria (e.g. methicillin-resistant Staphylococcus aureus) are screened [55], this practice breaks with tradition in management of respiratory viral illness. Testing is key as it has been extensively demonstrated that there are high proportions of asymptomatic, and more importantly pauci-symptomatic and pre-symptomatic individuals. Having a low threshold for testing allows for prompt identification of cases which can be managed by transferring detected patients to dedicated cohorting wards, isolation precautions, and quarantine (for HCWs and contacts). It seems suitable to perform wide-scale screening of both patients and HCWs, including asymptomatic individuals, in the event that COVID19 cases are identified in "non-COVID" wards to help (1) identify a potential outbreak situation, and (2) being able to control it. These strategies should, preferably, be integrated into a hospital-wide surveillance system that may have variable degrees of sophistication and/or automation [56].

Accordingly, universal testing of patients upon admission has also been an innovative implemented strategy. In a Hospital in New York City, between March 22 and April 4, 2020, in a period of high community transmission of SARS-CoV-2, a universal testing strategy for all women admitted for delivery was implemented [57]. From the 215 admitted pregnant women, 4 presented symptoms and tested positive for COVID-19; from the remaining asymptomatic 211 women, 29 tested positive for SARS-CoV-2 infection; therefore, $87.9 \%$ of all the admitted pregnant women who had COVID-19, were asymptomatic at admission. However, in an area with low COVID-19 prevalence, universal screening for 
SARS-CoV-2 upon hospital admission revealed a small number of asymptomatic admitted patients [58].

The importance of testing of HCWs should also be underlined. As a matter of fact, in the context of outbreaks in the healthcare setting, this is a strategy that has been successfully implemented. In Minnesota, during an outbreak in a LTCF, serial testing of patients and HCWs every 7-10 days revealed to be an important infection control practice [12]. Generalized testing of HCWs has also been implemented outside the context of outbreaks in LTCF. In Egypt, HCWs were tested for SARS-CoV-2 infection either by PCR or by rapid IgM and IgG serological tests: of the 4040 screened HCWs, 170 (4.5\%) were positive, with a high proportion of asymptomatic individuals [59]. A strategy of point-of-care testing, with antigen or rapid molecular testing has already been evaluated by a Cochrane Review; although it is mentioned that rapid testing may be valuable, more prospective studies in clinical settings should be performed [60].

Universal masking, including in non-clinical areas of healthcare settings, has also been commonly reported $[20,34,41,50,53,61-63]$, and may be useful in the context of presenteeism. Another commonly reported measure is visitor restrictions $[34,40,41,50,53,54,61,63,64]$. This is equally important for visitors to "non-COVID" wards (to protect the potentially uninfected patients and staff) and "COVID" wards (to prevent transmission to the potentially uninfected visitor and staff). However, pre-emptive visitor restrictions (i.e. in the absence of an outbreak) should be balanced with the mental health and quality of life of the residents [65]. Strategies to implement physical distancing inside the hospital premises, such as changing in-person meetings to virtual meetings or reorganization of the workplace can also be important measures to reduce the nosocomial transmission of SARS-CoV-2 [66].

A few Asian countries (South Korea, Taiwan, Singapore) implemented aggressive preventive strategies based on their experience with SARS-CoV-1 and MERS-CoV, combining several of the above mentioned IPC elements, mostly garnered with success in their healthcare settings $[20,64,67]$. It remains to be determined which of those elements should be routinely recommended for the $2^{\text {nd }}$ COVID-19 wave, to be expected in the next 12 months in most parts of the northern hemisphere.

\section{Expanding the research agenda}

Since the beginning of the COVID-19 pandemic, numerous countries have reported variable rates of $\mathrm{HCW}$ infections, some of whom unfortunately succumbed to the infection. Therefore, protection of HCWs is a key priority whilst caring for COVID-19 infected patients. The debate is focused almost predominantly on the use of PPE [68], and there predominantly on selecting different types of face masks, instead of investigating other potential sources for HCW infection $[69,70]$. Whilst it is clear that PPE availability is crucial, it is all the more important to ensure appropriate use of PPE, including type of PPE (e.g. surgical mask versus other), indications for PPE use; due to constraints imposed by physical distancing and workload of IPC professionals, training may be delivered by e-learning methods [71, 72]. The effect of education and training, which can also emphasise other key concepts such as prevention of presenteeism, on nosocomial infections can be explored through web-based trials [73-75].

Given that the role of HCWs remains unclear, it is necessary to conduct studies to better distinguish community-acquired HCW infection versus patient-to$\mathrm{HCW}$ transmission versus $\mathrm{HCW}$-to-HCW transmission (Fig. 1). The results of these in-depth analyses will allow us to improve our understanding of SARS-CoV-2 transmission dynamics, but even more, selecting appropriate prevention measures that go beyond taking on mask types. Today, many hospitals care for COVID-19- and non-COVID-19 patients at the same time. The latter must be protected from healthcare-associated acquisition of SARS-CoV-2 during their hospital stay, and we should use the time now to anticipate better prevention strategies before the next wave of COVID-19.

As of 20 May 2020, only three studies (out of 1,621 studies on COVID-19) have been registered in the clinicaltrials.gov database with the aim of understanding nosocomial healthcare-associated transmission of SARS-CoV-2: NCT04290780, NCT04339881, and NCT04356560. From the brief summaries provided, none of these studies focus on LTCFs or geriatrics. The role of universal screening of HCWs versus targeted screening, e.g. in high-risk units (which have yet to be defined), also has a place in the research agenda.

Outbreak investigations using epidemiological techniques are the current "gold standard", as they provide crucial spatial and temporal data on the outbreak and possible transmission routes, but also provide individual-level data such as risk factors for acquisition [76]. Nevertheless, the strengths of epidemiological outbreak investigations can be augmented by analysing genetic data. High-resolution data, such as that obtained by whole-genome sequencing, can contribute to discriminating between multiple clusters or introductions of disease within an outbreak, as well as characterizing the routes of transmission [77]. Genomic sequencing can be used to infer phylogenetic trees in order to establish contact networks that may have been unidentified by epidemiological analysis alone. However, when used alone, phylogenetic reconstruction are not without limitations, 
including lack of sensitivity, for example due to lower mutation rates $[78,79]$. Therefore, the powerful combination of epidemiological and genetic approaches [44], which has also been previously used for other diseases, combines the advantages of each individual approach and allows the limitations of one to be compensated by the other [80,81].

\section{Conclusions}

The debate revolving protection against SARS-CoV-2 infection in healthcare settings has been dominated by risk of patient-to-HCW transmission and the type of PPE (N95/respirator vs. facemask) to be used for its prevention. However, it is equally important to consider protecting patients from $\mathrm{HCW}$-to-patient transmission, considering the dire consequences of COVID-19. There has been a paradigm shift in outbreak management practices, that includes widespread testing of patients (or residents) and HCWs, including asymptomatic individuals. A low threshold is required in order to trigger actions to control nosocomial outbreaks and prevent further occurrences. Finally, it is crucial to deepen our understanding transmission pathways of healthcare-associated outbreaks, including the complex interplay between and respective role of $\mathrm{HCWs}$ and patients in transmission, in order to inform infection prevention guidelines and enhance protection of $\mathrm{HCWs}$ and patients.

\section{Acknowledgements}

We would like to thank Mr. Guy Dub, designer, for his help in creating the illustrations in the figure.

\section{Authors' contributions}

$\mathrm{MA}$ and $\mathrm{SH}$ conceived the structure of the manuscript and did the initial literature search. All authors commented on the manuscript and provided critical input, and agreed on the final version for publication. All authors read and approved the final manuscript.

\section{Funding}

MA is supported by a research fellowship from Geneva University Hospitals. TR is supported by a grant from the Swiss National Science Foundation (Grant No. 4078PO_198363).

\section{Ethics approval and consent to participate}

Not applicable.

\section{Consent for publication}

Not applicable.

Availability of data and materials

Not applicable.

\section{Competing interests}

All authors have no competing interests to declare.

\footnotetext{
Author details

${ }^{1}$ Infection Control Programme, Geneva University Hospitals and Faculty of Medicine, Geneva, Switzerland. ${ }^{2}$ Health Protection Research Unit, Imperial College London, London, UK. ${ }^{3}$ Infectious Diseases Service, Hospital Garcia de Orta, EPE, Almada, Portugal. ${ }^{4}$ University of Geneva, Geneva, Switzerland.
}

Received: 22 July 2020 Accepted: 22 December 2020

Published online: 06 January 2021

\section{References}

1. Federal Office of Public Health. Situation report on the epidemiological situation in Switzerland and the Principality of Liechtenstein. https:// www.bag.admin.ch/dam/bag/fr/dokumente/mt/k-und-i/aktuelle-ausbr ueche-pandemien/2019-nCoV/covid-19-lagebericht.pdf.download.pdf/ COVID-19_Situation_epidemiologique_en_Suisse.pdf. Accessed 30 June 2020.

2. PHE, NHSX. Coronavirus (COVID-19) in the UK. https://coronavirus-stagi ng.data.gov.uk/. Accessed 30 June 2020.

3. Santé Publique France. COVID-19: point épidémiologique du 18 juin 2020. https://www.santepubliquefrance.fr/maladies-et-traumatismes/ maladies-et-infections-respiratoires/infection-a-coronavirus/documents/ bulletin-national/covid-19-point-epidemiologique-du-18-juin-2020. Accessed 30 June 2020.

4. Griffin KM, Karas MG, Ivascu NS, Lief L. Hospital preparedness for COVID19: a practical guide from a critical care perspective. Am J Respir Crit Care Med. 2020;201:1337-44.

5. Carenzo L, Costantini E, Greco M, Barra FL, Rendiniello V, Mainetti M, et al. Hospital surge capacity in a tertiary emergency referral centre during the COVID-19 outbreak in Italy. Anaesthesia. 2020;75:928-34.

6. Swissnoso. Mesures provisoires de précautions dans les hôpitaux pour un patient hospitalisé avec suspicion d'infection COVID-19 ou présentant une infection COVID-19 confirmée. https://www.swissnoso.ch/fileadmin/ swissnoso/Dokumente/5_Forschung_und_Entwicklung/6_Aktuelle_Errei gnisse/200505_UPDATE_Mesures_de_precautions_COVID-19_hopit al_V_7.2_FR.pdf. Accessed 18 May 2020.

7. Centers for Disease Control and Prevention (CDC). Interim infection prevention and control recommendations for patients with suspected or confirmed coronavirus disease 2019 (COVID-19) in healthcare settings. https://www.cdc.gov/coronavirus/2019-ncov/hcp/infection-controlrecommendations.html. Accessed 12 May 2020.

8. Public Health England. Reducing the risk of transmission of COVID-19 in the hospital setting. https://www.gov.uk/government/publications/ wuhan-novel-coronavirus-infection-prevention-and-control/reducingthe-risk-of-transmission-of-covid-19-in-the-hospital-setting. Accessed 12 May 2020.

9. World Health Organization. Infection prevention and control during health care when COVID-19 is suspected. Interim guidance 19 March 2020. https://apps.who.int/iris/rest/bitstreams/1272420/retrieve. Accessed 12 May 2020.

10. Asad H, Johnston C, Blyth I, Holborow A, Bone A, Porter L, et al. health care workers and patients as Trojan horses: a COVID19 ward outbreak. Infect Prev Pract. 2020;2(3):100073.

11. Sikkema RS, Pas SD, Nieuwenhuijse DF, O'Toole A, Verweij J, van der Linden A, et al. COVID-19 in health-care workers in three hospitals in the south of the Netherlands: a cross-sectional study. Lancet Infect Dis. 2020;20(11):1273-80.

12. Taylor J, Carter RJ, Lehnertz N, Kazazian L, Sullivan M, Wang X, et al. Serial testing for SARS-CoV-2 and virus whole genome sequencing inform infection risk at two skilled nursing facilities with COVID-19 outbreaks-Minnesota, April-June 2020. MMWR Morb Mortal Wkly Rep. 2020;69(37):1288-95.

13. Chou R, Dana T, Buckley DI, Selph S, Fu R, Totten AM. Epidemiology of and risk factors for coronavirus infection in health care workers: a living rapid review. Ann Intern Med. 2020;173:120-36.

14. Sun H, Lu M, Chen S, Cheng Z, Xiong Y, Wang X. Nosocomial SARS$\mathrm{CoV}-2$ infection among nurses in Wuhan at a single centre. J Infect. 2020;80(6):e41-2.

15. Wei XS, Wang XR, Zhang JC, Yang WB, Ma WL, Yang BH, et al. A cluster of health care workers with COVID-19 pneumonia caused by SARSCoV-2. J Microbiol Immunol Infect. 2020;S1684-1182(20)30107-9.

16. Ran L, Chen X, Wang Y, Wu W, Zhang L, Tan X. Risk factors of healthcare workers with corona virus disease 2019: a retrospective cohort study in a designated hospital of Wuhan in China. Clin Infect Dis. 2020;71:2218-21. 
17. Istituto Superiore di Sanità. Integrated surveillance of COVID-19 in Italy. https://www.epicentro.iss.it/en/coronavirus/bollettino/Infografic a_6maggio\%20ENG.pdf. Accessed 08 May 2020.

18. The Guardian. Number of key workers getting Covid-19 overtakes positive tests in hospitals (05.05.2020). https://www.theguardian.com/ world/2020/may/05/number-of-key-workers-getting-covid-19-overt akes-positive-tests-in-hospitals. Accessed 21 May 2020.

19. Black JRM, Bailey C, Przewrocka J, Dijkstra KK, Swanton C. COVID-19: the case for health-care worker screening to prevent hospital transmission. Lancet. 2020;395(10234):1418-20.

20. Wong SC, Kwong RT, Wu TC, Chan JWM, Chu MY, Lee SY, et al. Risk of nosocomial transmission of coronavirus disease 2019: an experience in a general ward setting in Hong Kong. J Hosp Infect. 2020;105:119-27.

21. Kluytmans-van den Bergh MFQ, Buiting AGM, Pas SD, Bentvelsen RG, van den Bijllaardt W, van Oudheusden AJG, et al. Prevalence and clinical presentation of health care workers with symptoms of coronavirus disease 2019 in 2 Dutch hospitals during an early phase of the pandemic. JAMA Netw Open. 2020;3(5):e209673.

22. Treibel TA, Manisty C, Burton M, McKnight Á, Lambourne J, Augusto JB, et al. COVID-19: PCR screening of asymptomatic health-care workers at London hospital. The Lancet. 2020;395:1608-10.

23. Hunter E, Price DA, Murphy E, van der Loeff IS, Baker KF, Lendrem D, et al. First experience of COVID-19 screening of health-care workers in England. The Lancet. 2020;395(10234):e77-8.

24. Xiang B, Li P, Yang X, Zhong S, Manyande A, Feng M. The impact of novel coronavirus SARS-COV-2 among healthcare workers in hospitals: an aerial overview. Am J Infect Control. 2020;48:915-7.

25. Office for National Statistics. Coronavirus (COVID-19) related deaths by occupation, England and Wales: deaths registered up to and including 20 April 2020. https://www.ons.gov.uk/peoplepopulationandcommun ity/healthandsocialcare/causesofdeath/bulletins/coronaviruscovid19re lateddeathsbyoccupationenglandandwales/deathsregisteredupto andincluding20april2020. Accessed 18 May 2020.

26. Merçay C, Burla L, Widmer M. Personnel de santé en Suisse. Etat des lieux et projections à I'horizon 2030 (Obsan Rapport 71). Neuchâtel: Observatoire suisse de la santé, 2016.

27. Davies NG, Klepac P, Liu Y, Prem K, Jit M. CMMID COVID-19 working group, Eggo RM. Age-dependent effects in the transmission and control of COVID-19 epidemics. Nat Med. 2020;26(8):1205-11.

28. Rivett L, Sridhar S, Sparkes D, Routledge M, Jones NK, Forrest S, et al. Screening of healthcare workers for SARS-CoV-2 highlights the role of asymptomatic carriage in COVID-19 transmission. Elife. 2020;9:e58728.

29. Tartari E, Saris K, Kenters N, Marimuthu K, Widmer A, Collignon P, et al. Not sick enough to worry? "Influenza-like" symptoms and work-related behavior among healthcare workers and other professionals: results of a global survey. PLoS ONE. 2020;15(5):e0232168.

30. Chow EJ, Schwartz NG, Tobolowsky FA, Zacks RLT, Huntington-Frazier $M$, Reddy SC, et al. Symptom screening at illness onset of health care personnel with SARS-CoV-2 infection in King County, Washington. JAMA. 2020;323:2087-9.

31. Mossad SB, Deshpande A, Schramm S, Liu X, Rothberg MB. Working despite having influenza-like illness: results of an anonymous survey of healthcare providers who care for transplant recipients. Infect Control Hosp Epidemiol. 2017;38(8):966-9.

32. Wang X, Zhou Q, He Y, Liu L, Ma X, Wei X, et al. Nosocomial outbreak of 2019 novel coronavirus pneumonia in Wuhan, China. Eur Respir J. 2020;55:2000544.

33. Lauer SA, Grantz KH, Bi Q, Jones FK, Zheng Q, Meredith HR, et al. The incubation period of coronavirus disease 2019 (COVID-19) from publicly reported confirmed cases: estimation and application. Ann Intern Med. 2020;172(9):577-82.

34. Arons MM, Hatfield KM, Reddy SC, Kimball A, James A, Jacobs JR, et al. Presymptomatic SARS-CoV-2 infections and transmission in a skilled nursing facility. N Engl J Med. 2020;382:2081-90.

35. Wu Z, McGoogan JM. Characteristics of and important lessons from the coronavirus disease 2019 (COVID-19) outbreak in China: summary of a report of 72314 cases from the Chinese Center for Disease Control and Prevention. JAMA. 2020;323:1239-42.

36. Public Health England. Outbreaks in care homes in England. https://asset s.publishing.service.gov.uk/government/uploads/system/uploads/attac
hment_data/file/894997/COVID19_Care_Homes_24_June.pdf. Accessed 30 June 2020.

37. Département de la sécurité de l'emploi et de la santé (DSES) - Canton de Genève. Point épidémiologique hebdomadaire - Situation semaine 26 - 22 juin au 28 juin 2020. https://www.ge.ch/document/covid-19-point -situation-epidemiologique-hebdomadaire. Accessed 02 July 2020.

38. Hoxha A, Wyndham-Thomas C, Klamer S, Dubourg D, Vermeulen M, Hammami N, et al. Asymptomatic SARS-CoV-2 infection in Belgian long-term care facilities. Lancet Infect Dis. 2020;S1473-3099(20)30560-0.

39. Graham NSN, Junghans C, Downes R, Sendall C, Lai H, McKirdy A, et al. SARS-CoV-2 infection, clinical features and outcome of COVID-19 in United Kingdom nursing homes. J Infect. 2020;81:411-9.

40. McMichael TM, Currie DW, Clark S, Pogosjans S, Kay M, Schwartz NG, et al. Epidemiology of Covid-19 in a long-term care facility in King County, Washington. N Engl J Med. 2020;382:2005-11.

41. Kimball A, Hatfield KM, Arons M, James A, Taylor J, Spicer K, et al. Asymptomatic and presymptomatic SARS-CoV-2 infections in residents of a long-term care skilled nursing facility-King County, Washington, March 2020. MMWR Morb Mortal Wkly Rep. 2020;69(13):377-81.

42. Wang D, Hu B, Hu C, Zhu F, Liu X, Zhang J, et al. Clinical characteristics of 138 hospitalized patients with 2019 novel coronavirus-infected pneumonia in Wuhan, China. JAMA. 2020;323:1061-9.

43. The Guardian. Up to $20 \%$ of hospital patients with Covid-19 caught it at hospital. https://www.theguardian.com/world/2020/may/17/hospitalpatients-england-coronavirus-covid-19. Accessed 21 May 2020.

44. Meredith LW, Hamilton WL, Warne B, Houldcroft CJ, Hosmillo M, Jahun AS, et al. Rapid implementation of SARS-CoV-2 sequencing to investigate cases of health-care associated COVID-19: a prospective genomic surveillance study. Lancet Infect Dis. 2020;20:1263-72.

45. Flaxman S, Mishra S, Gandy A, Unwin HJT, Mellan TA, Coupland H, et al. Estimating the effects of non-pharmaceutical interventions on COVID-19 in Europe. Nature. 2020;584:257-61.

46. Klompas M. Coronavirus disease 2019 (COVID-19): protecting hospitals from the invisible. Ann Intern Med. 2020;172(9):619-20.

47. Schwierzeck V, Konig JC, Kuhn J, Mellmann A, Correa-Martinez CL, Omran $\mathrm{H}$, et al. First reported nosocomial outbreak of severe acute respiratory syndrome coronavirus 2 (SARS-CoV-2) in a pediatric dialysis unit. Clin Infect Dis. 2020; ciaa491.

48. Ng K, Poon BH, Kiat Puar TH, Shan Quah JL, Loh WJ, Wong YJ, et al. COVID19 and the risk to health care workers: a case report. Ann Intern Med. 2020;172:766-7.

49. Lessels R, Moosa Y, De Oliveira T. Report into a nosocomial outbreak of coronavirus disease 2019 (COVID-19) at Netcare St. Augustine's Hospital. 15 May 2020. https://www.krisp.org.za/manuscripts/StAugustinesHos pitalOutbreaklnvestigation_FinalReport_15may2020.pdf. Accessed 26 May 2020.

50. Rickman HM, Rampling T, Shaw K, Martinez-Garcia G, Hail L, Coen P, et al. Nosocomial transmission of COVID-19: a retrospective study of 66 hospital-acquired cases in a London teaching hospital. Clin Infect Dis. 2020; ciaa816.

51. Baker MA, Rhee C, Fiumara K, Bennett-Rizzo C, Tucker R, Williams SA, et al. COVID-19 infections among healthcare workers exposed to a patient with a delayed diagnosis of COVID-19. Infect Control Hosp Epidemiol. 2020;41(9):1075-6.

52. Dora AV, Winnett A, Jatt LP, Davar K, Watanabe M, Sohn L, et al. Universal and serial laboratory testing for SARS-CoV-2 at a long-term care skilled nursing facility for veterans-Los Angeles, California, 2020. MMWR Morb Mortal Wkly Rep. 2020;69(21):651-5.

53. Patel MC, Chaisson LH, Borgetti S, Burdsall D, Chugh RK, Hoff CR, et al. Asymptomatic SARS-CoV-2 infection and COVID-19 mortality during an outbreak investigation in a skilled nursing facility. Clin Infect Dis. 2020;ciaa763.

54. Roxby AC, Greninger AL, Hatfield KM, Lynch JB, Dellit TH, James A, et al. Outbreak Investigation of COVID-19 among residents and staff of an independent and assisted living community for older adults in Seattle, Washington. JAMA Intern Med. 2020;180:1101-5.

55. Albrich WC, Harbarth S. Health-care workers: source, vector, or victim of MRSA? Lancet Infect Dis. 2008;8(5):289-301.

56. Price JR, Mookerjee S, Dyakova E, Myall A, Leung W, Weisse AY, et al. Development and delivery of a real-time hospital-onset COVID-19 surveillance system using network analysis. Clin Infect Dis. 2020;ciaa892 
57. Sutton D, Fuchs K, D'Alton M, Goffman D. Universal Screening for SARS-CoV-2 in Women Admitted for Delivery. N Engl J Med. 2020;382(22):2163-4.

58. Sastry SR, Pryor R, Raybould JE, Reznicek J, Cooper K, Patrick A, et al. Universal screening for the SARS-CoV-2 virus on hospital admission in an area with low COVID-19 prevalence. Infect Control Hosp Epidemiol. 2020;41(10):1231-3.

59. Mostafa A, Kandil S, El-Sayed MH, Girgis S, Hafez H, Yosef M, et al. Universal COVID-19 screening of 4040 health care workers in a resource-limited setting: an Egyptian pilot model in a university with 12 public hospitals and medical centers. Int J Epidemiol. 2020.

60. Dinnes J, Deeks JJ, Adriano A, Berhane S, Davenport C, Dittrich S, et al. Rapid, point-of-care antigen and molecular-based tests for diagnosis of SARS-CoV-2 infection. Cochrane Database Syst Rev. 2020;8:CD013705.

61. Luong-Nguyen M, Hermand H, Abdalla S, Cabrit N, Hobeika C, Brouquet A, et al. Nosocomial infection with SARS-Cov-2 within Departments of Digestive Surgery. J Visc Surg. 2020;157:S13-8.

62. Kabesch M, Roth S, Brandstetter S, Hausler S, Juraschko E, Weigl M, et al. Successful containment of Covid-19 outbreak in a large maternity and perinatal center while continuing clinical service. Pediatr Allergy Immunol. 2020;31:560-4.

63. Schneider KN, Correa-Martinez CL, Gosheger G, Rickert C, Schorn D, Mellmann A, et al. Assessing the spreading potential of an undetected case of COVID-19 in orthopaedic surgery. Arch Orthop Trauma Surg. 2020;1-7.

64. Cheng VCC, Wong SC, Chen JHK, Yip CCY, Chuang VWM, Tsang OTY, et al. Escalating infection control response to the rapidly evolving epidemiology of the coronavirus disease 2019 (COVID-19) due to SARS-CoV-2 in Hong Kong. Infect Control Hosp Epidemiol. 2020;41(5):493-8.

65. The Guardian. Calls to lift lockdown in UK care homes over fears for residents' mental health. https://www.theguardian.com/society/2020/ may/30/calls-to-lift-lockdown-in-uk-care-homes-over-fears-for-residentsmental-health. Accessed 30 June 2020.

66. Arora VM, Chivu M, Schram A, Meltzer D. Implementing physical distancing in the hospital: a key strategy to prevent nosocomial transmission of COVID-19. J Hosp Med. 2020;15(5):290-1.

67. Peck KR. Early diagnosis and rapid isolation: response to COVID-19 outbreak in Korea. Clin Microbiol Infect. 2020;26(7):805-7.

68. Sommerstein R, Fux CA, Vuichard-Gysin D, Abbas M, Marschall J, Balmelli $C$, et al. Risk of SARS-CoV-2 transmission by aerosols, the rational use of masks, and protection of healthcare workers from COVID-19. Antimicrob Resist Infect Control. 2020;9(1):100.

69. Harding $\mathrm{H}$, Broom A, Broom J. Aerosol generating procedures and infective risk to healthcare workers: SARS-CoV-2 - the limits of the evidence. J Hosp Infect. 2020;105:717-25.

70. Rhee C, Baker MA, Klompas M. The COVID-19 infection control arms race. Infect Control Hosp Epidemiol. 2020;41(11):1323-5.

71. Suppan M, Gartner B, Golay E, Stuby L, White M, Cottet P, et al. Teaching adequate prehospital use of personal protective equipment during the COVID-19 pandemic: development of a Gamified e-learning module. JMIR Serious Games. 2020;8(2):e20173.

72. Suppan M, Catho G, Robalo Nunes T, Sauvan V, Perez M, Graf C, et al. A serious game designed to promote safe behaviors among health care workers during the COVID-19 pandemic: development of "Escape COVID19." JMIR Serious Games. 2020;8(4):e24986.

73. Suppan L, Abbas M, Stuby L, Cottet P, Larribau R, Golay E, et al. Effect of an E-learning module on personal protective equipment proficiency among prehospital personnel: web-based randomized controlled trial. J Med Internet Res. 2020;22(8):e21265

74. Suppan L, Stuby L, Gartner B, Larribau R, Iten A, Abbas M, et al. Impact of an e-learning module on personal protective equipment knowledge in student paramedics: a randomized controlled trial. Antimicrob Resist Infect Control. 2020;9(1):185

75. Suppan L, Abbas M, Catho G, Stuby L, Regard S, Harbarth S, et al. Impact of a serious game on the intention to change infection prevention and control practices in nursing homes during the COVID-19 pandemic: protocol for a web-based, randomized controlled trial. JMIR Res Protoc 2020;9:e25595.

76. Reingold AL. Outbreak investigations - a perspective. Emerg Infect Dis. 1998:4(1):21-7.

77. Grad YH, Lipsitch M. Epidemiologic data and pathogen genome sequences: a powerful synergy for public health. Genome Biol. 2014;15(11):538.

78. Frost SD, Pybus OG, Gog JR, Viboud C, Bonhoeffer S, Bedford T. Eight challenges in phylodynamic inference. Epidemics. 2015;10:88-92.

79. Campbell F, Strang C, Ferguson N, Cori A, Jombart T. When are pathogen genome sequences informative of transmission events? PLoS Pathog. 2018;14(2):e1006885.

80. Ypma RJ, Bataille AM, Stegeman A, Koch G, Wallinga J, van Ballegooijen WM. Unravelling transmission trees of infectious diseases by combining genetic and epidemiological data. Proc Biol Sci. 2012;279(1728):444-50.

81. Zingg W, Park BJ, Storr J, Ahmad R, Tarrant C, Castro-Sanchez E, et al. Technology for the prevention of antimicrobial resistance and healthcareassociated infections; 2017 Geneva IPC-Think Tank (part 2). Antimicrob Resist Infect Control. 2019;8:83.

82. Li YK, Peng S, Li LQ, Wang Q, Ping W, Zhang N, et al. Clinical and transmission characteristics of Covid-19-a retrospective study of 25 cases from a single thoracic surgery department. Curr Med Sci. 2020;40(2):295-300.

83. Vanhems P. Fast nosocomial spread of SARS-CoV2 in a French geriatric unit Lyon Study Group on Covid-19 infection. Infect Control Hosp Epidemiol. 2020;41(7):866-7.

84. Wee LE, Sim XYJ, Conceicao EP, Aung MK, Goh JQ, Yeo DWT, et al. Containment of COVID-19 cases among healthcare workers: the role of surveillance, early detection, and outbreak management. Infect Control Hosp Epidemiol. 2020;41(7):765-71.

85. Heinzerling A, Stuckey MJ, Scheuer T, Xu K, Perkins KM, Resseger H, et al. Transmission of COVID-19 to health care personnel during exposures to a hospitalized patient-Solano County, California, February 2020. MMWR Morb Mortal Wkly Rep. 2020;69(15):472-6.

86. National Health Service (England). Healthcare associated COVID-19 infections - further action. https://www.england.nhs.uk/coronavirus/ wp-content/uploads/sites/52/2020/06/Healthcare-associated-COVID -19-infections--further-action-24-June-2020.pdf. Accessed 30 June 2020.

87. Public Health Agency of Canada. Infection prevention and control for COVID-19: Interim guidance for long term care homes. https://www. canada.ca/en/public-health/services/diseases/2019-novel-coronaviru s-infection/prevent-control-covid-19-long-term-care-homes.html. Accessed 30 June 2020.

88. Health Protection Surveillance Centre (Ireland). COVID-19 case definitions. https://www.hpsc.ie/a-z/respiratory/coronavirus/novelcoronavirus/ casedefinitions/. Accessed 30 June 2020.

89. Swissnoso. Prevention \& control of healthcare-associated COVID-19 outbreaks. https://www.swissnoso.ch/fileadmin/swissnoso/Dokum ente/5_Forschung_und_Entwicklung/6_Aktuelle_Erreignisse/20051 5_Prevention_and_control_of_healthcare-associated_COVID-19_outbr eaks V1.0_ENG.pdf. Accessed 30 June 2020

90. Centers for Disease Control and Prevention (CDC). Responding to coronavirus (COVID-19) in nursing homes. https://www.cdc.gov/coronaviru s/2019-ncov/hcp/nursing-homes-responding.html. Accessed 30 June 2020.

91. Centers for Disease Control and Prevention (CDC). Testing guidelines for nursing homes. https://www.cdc.gov/coronavirus/2019-ncov/hcp/nursi ng-homes-testing.html. Accessed 30 June 2020.

\section{Publisher's Note}

Springer Nature remains neutral with regard to jurisdictional claims in published maps and institutional affiliations. 